\title{
FOLK MEDICAL INHALANTS IN RESPIRATORY DISORDERS*
}

\author{
by \\ WAYLAND D. HAND
}

SEVERAL years ago as I began to work through my voluminous files on American folk medicine, $\mathrm{I}$ became interested in some of the unusual remedies that have been employed to combat respiratory ailments in the United States and Canada. This interest was considerably heightened in 1964 when two Virginia scholars called attention to the use of grist mills in the treatment of whooping-cough in their own state and in the neighbouring state of West Virginia. ${ }^{1}$ Their search was prompted by a Pennsylvania Dutch custom, dating from the 1880 s, or before, of placing a child with whooping-cough in a hopper of grain in a grist mill until the grain was ground out. In the same year my research assistant and I made a preliminary survey of American folk medical prescriptions for the cure of respiratory ailments. ${ }^{2}$ On the basis of further study, I am now able to make a fuller statement. The survey is now being broadened to include material that has come to hand from the British Isles and from several countries of Europe.

An eighteenth-century Scottish physician, William Buchan, writing on chin-cough, or whooping-cough, in 1772, said that 'the most effective remedy in this disease is a change of air. This often removes the malady even when the change seems to be from a purer to a less wholesome air ...'3 Part of this prescription was the recommendation that the patient should be removed some distance from the place where he contracted the disease. These views on a change of air were widely accepted and became, or were already a part of the folk medical treatment of whooping-cough in the British Isles. ${ }^{4} \mathrm{~A}$ change of air has not been reported for the treatment of whooping-coughs or hiccoughs in the folklore literature from Scandinavia, Germany, the Low Countries, and France, but this may be due to the failure to collect and report this popular folk medical custom. In Spain, for example, croup, a malady of the throat which affects breathing in children, is treated by sending the patient into the mountains for a change of air. ${ }^{5}$ Likewise, children were carried to Gowk Craig in Forgan Parish in Fife so they could recover from whooping-cough by remaining for two hours where the 'seven airs' blow, and in the North Riding of Yorkshire patients ordered to go to the country for a change of air were told to seek a spot 'where three roads meet.' Another famous high place to which people with respiratory disorders went was the viaduct, Archway Road, Highgate, in the northern part of London. Nurses formerly took children to this spot, and people are reported to have come to the bridge from far and wide with their children. ${ }^{7}$ Tan-Hill was a north country place to which people in Lancashire and Westmorland also took their children for relief from whoopingcough. ${ }^{8}$ That faith in high ground and a change of air was generally believed as

* I am grateful to the University of California, Los Angeles, for making this study possible, and to the Wellcome Historical Medical Library and Museum in London for making its rich holdings in folk medical literature and the services of its staff available to me during an extended stay in London during the summer of 1966. 


\section{Wayland D. Hand}

being efficacious for the treatment of whooping-cough is seen in a cure performed in the 1880s in the West Riding of Yorkshire whereby the young patient was pulled under the stomach of a donkey three times in a passing-through ritual. The correspondent to Notes and Queries believed, however, that the cure was due in part to the fact that the ceremony was performed on a high hill where a change of air was an important factor in the cure. ${ }^{9}$ The taking of children with whooping-cough atop the Blackpool tower in Lancashire for a change of air, ${ }^{10}$ in very recent times is further evidence of the faith which people have in the beneficial effect of rarified atmosphere in the treatment of this disease. Even more striking are the so-called 'Nursery Flights' of the Royal Air Force station in Austria in 1955, in which the children of R.A.F. members suffering from whooping-cough were taken aloft to expose them to the low barometric pressure in aeroplanes flying at high altitudes. ${ }^{11}$

Mothers of Hull are reported to have taken their suffering youngsters across the Humber to New Holland and back again for the change of air this trip afforded. Such a mission was called 'crossing strange water.' ${ }^{12}$ Like the mountains, the seaside afforded a welcome change of air, and the sea air was sought by Lancashiremen and Westmorlanders for the treatment of whooping-cough. ${ }^{13}$ In the light of the examples cited, one might wonder if the prescription for whooping-cough, namely, to carry a child fasting into three parishes on a Sunday morning, as reported from Devonshire in the 1850s, might not somehow have involved, whatever other virtues, the change of air that such a lengthy journey might have entailed. ${ }^{14}$

Just as a change of air brought relief to sufferers from whooping-cough and other respiratory ailments, whether by trips to high places or to the seaside, so also were the natural earth fumes and gases thought to be beneficial. Making the whoopingcough patient follow the plough and inhale the smell of the newly turned land was widely reported in Essex, ${ }^{15}$ and no doubt regarded as beneficial elsewhere. In County Fife, likewise, the smell of freshly-dug earth was held to be beneficial for whoopingcough. Accordingly, a hole was dug in the earth and the patient made to breathe the emanations. ${ }^{16}$ In Norfolk and Suffolk a hole was dug in a meadow, and the child's head held in it until a cough was heard. ${ }^{17}$ Transference of the disease to the earth seems to have been involved in an Essex cure for the same disease. After the child's head had been held in the hole until he coughed, the hole was filled again and the cough left there with it. ${ }^{18}$ Sometime during the second half of the nineteenth century a group of sufferers from pulmonary tuberculosis were reported to have taken up residence in the Mammoth Cave in Kentucky for what benefits the air of the cave would bring, but the whole venture was a failure. Several died and the remainder returned to daylight with the chance of life sadly impaired. ${ }^{19}$

By way of analogy to natural caves in the earth, man-made holes such as mines and charcoal pits were used in the treatment of whooping-cough..$^{20}$ The patients were either held over the opening of the pit so as to breathe the escaping air, or they were actually taken into the mines on the advice of a physician, as in Scotland. ${ }^{21}$ In County Fife bread was taken into the pits, impregnated with the air of the mine, and then given to the patient for 'a change of air'. ${ }^{22} \mathrm{~A}$ beneficial change of air was likewise associated with lime kilns, where not only whooping-cough was treated, ${ }^{23}$ but also pulmonary tuberculosis. Patients suffering from this disease were encouraged to 


\section{Folk Medical Inhalants in Respiratory Disorders}

sleep near the old-fashioned open lime kilns, as in the Lake District. ${ }^{24}$ Apparently, belief in the so-called 'harmonious air' of lime kilns, ${ }^{25}$ also lay at the base of an Alabama belief in the efficacy of croup patients inhaling the fumes of unslaked lime to keep them from strangling. ${ }^{26}$

The custom of taking children suffering from whooping-cough to the gas-works has been reported from different parts of England and the United States, and the breathing of such air was likewise recommended as a cure for croup in Spain. ${ }^{27}$ Writing in 1879, William Henderson reports that a girl suffering from whoopingcough in one of the northern counties was taken several days successively to the gas-works to breathe what her mother called the 'harmonious air'. ${ }^{28}$ Children of Glasgow suffering from whooping-cough were taken to the gas-works for relief, ${ }^{29}$ as were those of Westmorland and Lancashire, ${ }^{30}$ while afflicted youngsters in Norfolk were encouraged to 'sit in the lee of the local gas works' ${ }^{31}$ This strange folk medical custom was also observed elsewhere in Scotland besides Glasgow. When an outbreak of whooping-cough occurred in County Fife in 1891, it was observed that the keeper of the gas-works did not take the complaint. This was explained as being due to the fact that the air near a gas-works contains pyradin, which is supposed to act as an antiseptic and a germicide. ${ }^{32}$ This is the only attempt at an explanation of the practice which I have encountered in the folklore literature, and may or may not have a basis in fact. The supposed cure of whooping-cough by the inhalation of ammoniacal fumes at a gas-works, turns up in one of the earliest American folklore publications, a small brochure dealing with beliefs and customs in and around Philadelphia in the late 1880 s. There are no details, simply the reporting of the fact that children could be cured by inhaling the ammoniacal fumes at the gas-works. ${ }^{33}$ In Adams County, Illinois, young sufferers from whooping-cough were taken to a gas-house and carried through the building several times. ${ }^{34}$ Related to breathing the vapours of gas-works is the breathing not only of fumes from chemical plants, as recommended in Scotland, ${ }^{35}$ but the vapours of distilleries also, as in Glasgow. ${ }^{36}$

More widely known geographically than any treatment involving mines, kilns, factories, or other industrial works is the curious custom, alluded to at the beginning of this article, of taking a child into a grist mill and holding it over the hopper. This practice is reported from the British Isles and Spain, and from several parts of the United States. In England and Scotland, inhalation of the dust from the mill is not specifically stated, as the child is pulled in and out of the hopper, often as many as nine times. ${ }^{37}$ In Ireland, likewise, the child was lifted rapidly into a mill hopper and out again three times in succession. ${ }^{38}$ In his three-volume medical dictionary of 1743-1745, in an entry under 'pertussis', Robert James explained the placing of a child in a grist mill as being done to induce fright, with the grinding of the wheels, the noise, etc. ${ }^{39}$ Credence is lent to this view by the practice in Galicia, Spain, of carrying a child nineteen times around the cogwheel of a mill, with no reference to placing the child near the hopper, nor even the intimation that it was specifically a grist mill, even though the word 'mill' generally connotes some sort of flour or grist mill. ${ }^{00}$ The theory of inducing sudden fright, as in the case of hiccoughs, is unknown to me, and does not occur in my files containing some five hundred entries on 'whooping-cough'. However, elements of fright to the child are seen in a folk medical 


\section{Wayland D. Hand}

ritual from the Ozarks where a child is taken to the grist mill to be 'ground in the hopper' for the cure of paralysis. ${ }^{41}$ American examples, apparently, never specifically mention inhalation of the air and dust from the mill hopper. In the twenty careful interviews made by Smith and Stewart in Virginia, West Virginia, and the Pennsylvania German country, breathing the emanations from the mill does not come up. Also, there is no lifting in and out of the hopper, as in the British Isles. Usually the child is placed in the mill 'until the grist is ground', as in Pennsylvania, ${ }^{42}$ 'until the mill grinds a half a bushel of corn', as in North Carolina, where the practice is carried out by Negroes as well as whites, ${ }^{43}$ or the child is made to sit in the hopper of a mill 'until the grain has run out', as in Illinois.4 It should be noted that children in the United States were also taken to grist mills as a preventive measure. ${ }^{45}$ The only place where the breathing of the dust from the freshly-ground flour and meal is specifically mentioned is from two different parts of Spain. In both cases the treatment is for whooping-cough. ${ }^{46}$

Other kinds of polluted air caused by industrial works, or products or waste products of their manufacture, together with emanations of smoke from other sources, can now be taken up as they relate to the curing of whooping-cough and other diseases, including the plague. The breathing of smoke from a railroad tunnel by patients while on a train, ${ }^{47}$ or their specifically entering a tunnel to inhale the smoke left in the tunnel after a train has passed through, is a custom reported from Spain as late as the 1940s. ${ }^{48}$ This latter practice also applied to the treatment of croup. ${ }^{49}$ In America resort to railroad tunnels for the cure of whooping-cough is reported only from the Pennsylvania German country. ${ }^{50}$ Miners in Pennsylvania and adjoining states where coal is mined believed that powder smoke was the only cure for whoopingcough, and fathers, accordingly, would carry their ailing youngsters into the mines to be exposed to the sulphurous fumes. ${ }^{51}$

Early in the nineteenth century, T. W. Wansbrough, a surgeon in Fulham, used tar vapour successfully in treating whooping-cough. He simply produced the vapour by sticking a hot poker into Barbadoes tar and letting the child breathe the fumes. ${ }^{52}$ Since relegated to the realm of folk medicine, this practice has continued in use until our own time. ${ }^{53}$ In Moby Dick (1851) Herman Melville tells how sailors, thinking they would catch the plague, would dip oakum into coal tar and hold it to their nostrils (ch. 91). Pine resin put into a pot of boiling water is used much the same way for the cure of croup in Alabama as the patient inhales the fumes. ${ }^{54}$ Breathing the smoke from pine knots taken from lumber was a method of treating croup in Texas. ${ }^{55}$

Among the kinds of 'less wholesome air', which William Buchan alluded to as being beneficial for the treatment of chin-cough in the eighteenth century, the following can be mentioned. Apart from gases and vapours of the kind we have just considered, there are human and animal odours of various kinds that are recommended in folk medicine. The holding of a child over a privy or commode for example is reported from both the British Isles and the United States. ${ }^{56}$ More widely known as a cure for respiratory ailments and throat infections was the air of the stable. In the Slavic countries and Germany tuberculars were taken into animal stalls, ${ }^{57}$ while asthma was treated in Holland in the same way. ${ }^{58} \mathrm{~A}$ cowstall is specifically mentioned. In Scotland patients suffering from whooping-cough were taken to a byre. If, during 


\section{Folk Medical Inhalants in Respiratory Disorders}

the process, the child gave a kink, or cough, it was considered a good sign. ${ }^{59}$ In Virginia, children with whooping-cough were allowed to play in the stable all day. ${ }^{60}$ A manure-pile ritual, wherein a child with thrush was held over a steaming manure pile, as a verbal charm was said over him in the three highest names, was reported from Indiana as late as the early $1960 \mathrm{~s}^{61}$

The breath and smell of a cow were considered good for consumption in Scotland, ${ }^{62}$ while the smell of sheep, particularly in the sheepfold, was recommended not only for whooping-cough pretty much throughout England and Scotland, but for other diseases as well, including bronchitis; consumption, and tuberculosis. In Somerset, for example, it is thought that one may still cure bronchitis simply by passing through a flock of sheep. ${ }^{63}$ In the shires of Dorset, Somerset, and Oxford, consumption was treated by having the patient enter a sheepfold, or walk around a sheepfold, very early in the morning, early enough in Dorsetshire, for example, to see the sun rise. ${ }^{64}$ Treatment in the sheepfold for whooping-cough is reported from Devonshire and Essex. ${ }^{65}$ In an earlier day it was sufficient for the patient simply to roll around on the spot where a sheep had bedded down for the night, the only stipulation being that the dew must still be on the field. ${ }^{66}$

Less well-known cures relating to animal odours and offensive emanations involve the breathing of the unpleasant smell of a goat or a fox for a week, ${ }^{67}$ and the taking of children to pigstyes before dawn and forcing them to bite into the hog trough. ${ }^{68}$ In the Bradford-Shipley district the smell of a maggot farm was thought to be beneficial for tuberculosis, and during World War I soldiers were marched through it to strengthen their resistance to tuberculosis. ${ }^{69}$ In Oklahoma the smell of the warm viscera of a slaughtered hog was recommended as a cure for a common cold and sore throat. ${ }^{70}$.

The inhalation of the breath of horses, mules, and donkeys, or oral contact with these creatures, is well known in the British Isles, but perhaps even more widely so in the United States. In Suffolk, for example, the custom is known as 'taking the horse's breath', ${ }^{71}$ and is reported from the early $1850 \mathrm{s.}^{72}$ The breath of a stallion was prescribed in Suffolk, ${ }^{73}$ and that of a piebald horse in Herefordshire. ${ }^{74}$ In 1882, a correspondent to Notes and Queries, area unstated, wrote that a cart-horse is supposed to snort into the face of a child suffering from whooping-cough, ${ }^{75}$ while across the Atlantic, in states as widely separated as Georgia, Tennessee, Kentucky, and Illinois, a stallion or a horse is made to snort or blow into a child's face for thrush (thrash) or tonsilitis. ${ }^{76}$ Running a horse or racing one until it froths at the mouth, and then holding a child with whooping-cough to its mouth is reported from both Maryland and Louisiana from the mid-1920s. ${ }^{77}$ Ten years later this custom was reported for the same disease from Illinois, but the case discussed was referable to about 1860 . It is specified that after racing a horse until it is almost out of breath, the child should breathe 'what little breath is left' in the horse's mouth. ${ }^{78} \mathrm{~A}$ stallion breathing into the throat of a child suffering from whooping-cough was recommended in North Carolina after World War $1,{ }^{79}$ while a white horse was specified for this special office in Mississippi as late as $1923 .{ }^{80}$

Contact with the mouth of animals involves an exchange of air, so the kissing of mules or donkeys deserves to be mentioned in connection with inhalation of the 


\section{Wayland D. Hand}

breath of animals. A sore throat in Ireland, for example, was cured by inhaling and swallowing the breath of a donkey three times in succession for three consecutive mornings. ${ }^{81}$ A Scottish curative ritual for whooping-cough involved inhaling the breath of an ass and then passing the patient under its belly and over its back. ${ }^{82}$ The only instance of a mule or donkey-kissing ritual for the cure of a respiratory ailment that I can turn up comes from Illinois, where it was known over twenty years ago. Kissing the nostrils of a mule, according to the belief, would cure catarrh. ${ }^{83}$

Close oral contact with other animals, including kissing, is seen in a Georgia cure for hiccoughs whereby the victim kisses a dog in the mouth, ${ }^{84}$ and an Irish and American treatment for sore throat, thrush, and whooping cough, which involves making a gander hiss or spit down the victim's throat. Details, unfortunately, are lacking. ${ }^{85}$

Fish were also pressed into service for the curing of whooping-cough. They were either held against the child's mouth so as to breathe down it, or the process was reversed, whereby the patient breathed down the fish's mouth, thus communicating the disease to the fish. Finally, live fish, usually minnows, were swallowed. Interesting though these two last-named categories are, I cannot treat them here. ${ }^{86}$ The breathing of fish down the throat of a sufferer from whooping-cough was known in the British Isles during the nineteenth century, ${ }^{87}$ and this old practice has lived on in twentiethcentury America. An interesting account of a young mother begging a fish from a fisherman along the banks of the Schuylkill River in the neighbourhood of Philadelphia around 1875, indicates that perhaps this custom is of long standing in America. ${ }^{88}$ Other cases of this custom have been reported from Pennsylvania. ${ }^{89}$

Frogs and toads were likewise held in the mouth or up to the mouth of a child, but it is not always clear whether the frog or toad blew into the child's mouth, or whether it sucked the child's breath and thus absorbed the disease. The reference given here for Shropshire may involve the same kinds of cures we have been discussing in connection with animals and fish, ${ }^{90}$ but in all of the rest of the cases cited from the British Isles, transference of the disease to the frog is either clearly indicated, or to be implied. ${ }^{91}$ The German and Dutch examples likewise emphasize transference of the disease to the frog. ${ }^{92}$ An American example from New York State also clearly deals with the transfer of the child's sore throat to the frog, which absorbs the poison and spits forth green froth. ${ }^{93}$ The holding of toads to a child's mouth in Cheshire for the cure of whooping-cough apparently involves a passage of air from the toad to the child, in the regular way, ${ }^{94}$ as does a case cited in the English Dialect Dictionary, wherein it is reported that a child could not 'get shut of the chin-cough, though he had sucked two toads to death. ${ }^{95}$

Though the drinking of a child from a bucket or from a drinking trough immediately after a horse has drunk has elements that are related to the practices under discussion, there is not space to enter upon a discussion of this matter here. Nor is there space to consider the drinking of milk by a child for various respiratory conditions after a cat, ferret, or fox has lapped milk from a saucer or other receptacle. At best these would represent only secondary contacts, for the exhalations of the animals over the milk would long since have been dissipated by the time the child could be brought to the vessel to drink. 


\section{Folk Medical Inhalants in Respiratory Disorders}

Finally, we come to a discussion of the use of the human breath in the curing of respiratory and throat ailments. Claiming our interest in this connection is the qualification of the person himself as a healer, whether he be a posthumous child, a child born with a caul, a seventh son, a seventh son of a seventh son, a third son of a third son, a daughter who has never known her father, or a woman whose last name remains unchanged after marriage. Once more, references from the British Isles and America predominate. In the North Riding of Yorkshire, for example, a female who never knew her father blew in the mouth of a child suffering from whooping-cough nine mornings in succession, this with fasting breath. ${ }^{96}$ Posthumous sons are credited with curing victims of whooping-cough in Georgia, Maryland, Illinois, ${ }^{97}$ and among the southern Negroes, ${ }^{98}$ and a child born with a caul was believed in Indiana to possess this same gift of curing whooping-cough. ${ }^{99}$ In Ireland a seventh son could cure thrush, so it was believed, by breathing into the mouth of a child, ${ }^{100}$ as could a posthumous son. ${ }^{101}$ A posthumous son, likewise, or the seventh son in a family, were believed in Indiana to have the gift of curing thrush in the aforesaid manner. ${ }^{102}$ In Kentucky a third son of a third son was thought to be thus endowed, ${ }^{103}$ while in Tennessee the healing power rested with a woman who had married without changing her name. ${ }^{104}$ Posthumous children, when grown, are also credited with being able to cure croup, as cases reported from Maryland and the Ozark country show. ${ }^{105}$

Finally, among the Pennsylvania Germans there is a belief that if a child kisses a Negro full in the mouth, he will be free of whooping-cough. ${ }^{106}$ Some say a lifelong immunity is built up by such a kiss if the act takes place while the child is under one year of age. ${ }^{107}$

Fumigation of all kinds, including the burning of animal and plant products and mineral compounds cannot be taken up here for lack of space, nor can the inhalation of water vapour, and the fumes of such common household remedies as vinegar (hot vinegar), turpentine, kerosene, creosote, sulphur, and the like. Many of these household remedies and treatments are so common as not to be of great concern in a paper devoted mainly to the more unusual kinds of inhalants.

The preponderance of data from the British Isles and America does not, it seems to me, invalidate the notion that the use of inhalants for respiratory ailments was once widespread throughout Europe, and perhaps still is known in many countries; it simply points out the need for more and better collecting, and for the researching of scattered materials that have not always found their way into the standard compilations of folk medicine, country by country.

\section{REFERENCES}

1. SMith, Elmer L., and Stewart, John, 'The mill as a preventive and cure of whoopingcough', J. Am. Folklore, 1964, 77, 76-77.

2. HAND, WaYland D., and GRIFFI, MarJorm, 'Inhalants in respiratory disorders', J. Am. Folklore, 1964, 77, 258-61.

3. Buchan, Winliam, Domestic Medicine, or, The Family Physician, Philadelphia, R. Aitken, 1772, p. 199.

4. Black, William George, Folk-Medicine: A Chapter in the History of Culture, Publications of the Folk-Lore Society, XII, London, 1883, p. 183; SIMPKINS, JoHN EWART, Examples of the Printed Folk-Lore Concerning Fife, With Some Notes on Clackmannan 


\section{Wayland D. Hand}

and Kinross-Shires, Publications of the Folk-Lore Society, LXXI, London, 1914, p. 408; Folk-Lore, 1943, 54, 305.

5. Castillo de Lucas, Antonio, Folkmedicina, Madrid, Editorial Dossat, 1958, p. 467.

6. SimpkINS, op. cit., p. 134; GuTCH, [ELIZA], Examples of Printed Folk-Lore Concerning the North Riding of Yorkshire, York, and the Ainsty, Publications of the Folk-Lore Society, XLV, London, 1901, p. 180.

7. Folk-Lore, 1926, 37, 367.

8. Folk-Lore, 1951, 62, 259, Moorland air recommended (ibid., no. 1).

9. Notes and Queries, 7th ser., vol. 4, 27 August, 1887, p. 176.

10. MCKelvie, Donald, 'Some Aspects of Oral, Social and Material Tradition in an Industrial Urban Area', unpublished, Ph.D. diss., Leeds, 1963, p. 279, no. 138.

11. Shrewsbury, John Findlay Drew, The Plague of the Philistines and other MedicalHistorical Essays, London, Victor Gollancz, 1964, p. 43.

12. RADBILL, SAmUEL X., 'Whooping-cough in fact and fancy', Bull. Hist. Med., 1943, 13, 49.

13. Folk-Lore, 1951, 62, 260, no. 11.

14. Notes and Queries, 1st ser., vol. 11, 31 March 1855, p. 239; BlAck, op. cit., p. 89; RADFORD, E., and RADFORD, M. A., Encyclopadia of Superstitions, London, Rider and Company, [1947], p. 231.

15. Folk-Lore, 1951, 62, 260.

16. Simpkins, op. cit., p. 408.

17. Folk-Lore, 1943, 54, 305.

18. Folk-Lore, 1951, 62, 260.

19. Western Folklore, 1961, $20,276$.

20. Folk-Lore, 1943, 54, 305 (mines); 1951, 62, 260 (charcoal pits).

21. [Morr, David MAcbeth], Mansie Wauch, Tailor of Dalkieth, New York, J. \& J. Harper, 1828, ch. XIII, 'The chincough pilgrimage'; SimPKINS, op. cit., p. 134 (for kingkost, local dialect name in County Fife for whooping-cough).

22. SimpKINS, op. cit., p. 408.

23. Balfour, M. C., and Thomas, Northcote W., Examples of Printed Folk-Lore Concerning Northumberland, Publications of the Folk-Lore Society, LIII, London, 1903, p. 49; SimpKIns, op. cit., p. 409; Folk-Lore, 1951, 62, 262.

24. Folk-Lore, 1951, 62, 256.

25. RADFORD, op. cit., p. 259.

26. Browne, RAY B., Popular Beliefs and Practices from Alabama, Folklore Studies, IX, Berkeley and Los Angeles, University of California Press, 1958, p. 19, no. 222.

27. Castillo de Lucas, op. cit., p. 467.

28. Henderson, William, Notes on the Folk-Lore of the Northern Counties and the Borders, Publications of the Folk-Lore Society, II, London, 1879, p. 142.

29. BlaCK, op. cit., p. 183; RADBILL, op. cit., p. 49; cf. p. 42, also.

30. Folk-Lore, 1951, 62, 260.

31. Folk-Lore, 1929, 40, 117.

32. SimpKINS, op. cit., p. 409.

33. Phillips, Henry, JR., 'First contribution to the folk-lore of Philadelphia and its vicinity', Proc. Amer. philos. Soc., XXV, no. 128, March 1888, p. 163, no. 11; cf. RADBILL, op. cit., p. 49.

34. Hyatt, HARRY Middleton. Folk-Lore from Adams County Illinois, New York, Alma Egan Hyatt Foundation, 1935, p. 212, no. 4413; HAND, WAYLAND D. (ed.). Frank C. Brown Collection of North Carolina Folklore, vols. 6-7, Durham, North Carolina, Duke University Press, 1961-1964, vol. 6, p. 68, no. 423.

35. NAPIER, JAMES, Folk-Lore: or, Superstitious Beliefs in the West of Scotland within this Century, Paisley, Alex. Gardner, 1879, p. 96.

36. BlACK, op. cit., p. 183; RADBILL, op. cit., p. 49.

37. RADBILl, op. cit., p. 42; Dal Yel, JoHn Graham, The Darker Superstitions of Scotland, Glasgow, Richard Griffin, 1835; p. 117; BLACK, op. cit., p. 119. 


\section{Folk Medical Inhalants in Respiratory Disorders}

38. Wood-Martin, W. G., Traces of the Elder Faiths of Ireland. A Folklore Sketch, 2 vols., London, Longman, Green, 1902, vol. 2, p. 189.

39. James, R., A Medicinal Dictionary, Including Physic, Surgery, Anatomy, Chymistry and Botany, etc., 3 vols., fol., London, 1743-1745, vol. 3, s.v. 'pertussis' [no pagination]: 'Another empirical Method of curing the Chin-cough, when Medicines prove ineffectual, is, to fright the Child, by putting it in the Hopper of a Mill, which makes a terrible Noise, and the Aspect of whose Wheels is dreadful; and by this Method a Chin-cough is sometimes suddenly cured; the Reason of which undoubtedly confits in this, not only that the animal Spirits, being, by the Fright, forced into new Distractions, leave their former inordinate Motions, but also, that the matter producing the Spasms is, by such Perturbation, either dissipated, or forced into other Nerves, where it proves less troublesome.'

40. Revista de Dialectología y Tradiciones Populares, 1947, 3, 567. (Hereinafter abbreviated: Rev. Dial. Trad. Pop.)

41. RandolPh, Vance, Ozark Superstitions, New York, Columbia University Press, 1947, p. 149.

42. J. Am. Folklore, 1891, 4, 125.

43. HAND, op. cit., VI, 67, no. 422.

44. Allen, JoHN W., Legends and Lore of Southern Illinois, Carbondale, Illinois, Southern Illinois University, 1963, p. 84.

45. On this phase of the treatment, and for other details, cf. the two articles in the J. Am. Folklore, refs. 1 and 2.

46. Rev. Dial. Trad. Pop., 1944, 1, 161 (Coruna); ibid., 1947, 3, 567 (Galicia).

47. Rev. Dial. Trad. Pop., 1949, 5, 505.

48. Rev. Dial. Trad. Pop., 1944, 1, 321.

49. Castillo de LuCAS, op. cit., p. 467.

50. FoGel, EDWIN M., 'Beliefs and superstitions of the Pennsylvania Germans', Americana Germanica, XVIII, Philadelphia, 1915, p. 339, no. 1806; RADBILL, op. cit., p. 42.

51. Korson, Grorge, Minstrels of the Mine Patch. Songs and Stories of the Anthracite Industry, Hatboro, Pa., Folklore Associates, 1964, pp. 146-47.

52. Lancet, 1828-1829, ii, 523-24.

53. Black, op. cit., p. 183; Folk-Lore, 1932, 43, 256 (Halifax); ibid., 1951, 62, 259, no. 2 (Essex, Westmorland, Lancashire); McKeLVIE, op. cit., pp. 278-79.

54. BROWNe, op. cit., p. 99, no. 1704.

55. Publications of the Texas Folklore Soc., 1938, 14, 268.

56. Folk-Lore, 1929, 40, 117; PuCKetT, NewBell NILEs, Folk Beliefs of the Southern Negro, Chapel Hill, N. C., University of North Carolina Press, 1926, pp. 371-72.

57. V. HovorkA, O., and KRONFELd, A., Vergleichende Volksmedizin, 2 vols., Stuttgart, Verlag von Strecker und Schröder, 1908-1909, vol. 2, 49.

58. VAN ANDEL, M. A., Volksgeneeskunst en Nederland, Utrecht, Boekhoven, 1909, p. 224.

59. NAPIER, op. cit., p. 96; cf. SimpKINs, op. cit., p. 408 (smell of the byre good for invalids generally).

60. PuCKeTt, op. cit., p. 371.

61. Midwest Folklore, 1961, 11, 47, no. 151; cf. Southern Folklore Quarterly, 1939, 3, 40, s.v. 'thrush', no. 4.

62. BLACK, op cit., p. 161 ; SIMPKINS, op. cit., 21, 133.

63. Tongue, R. L., and Brigas, K. M., Somerset Folklore, Publications of the Folk-Lore Society, CXIV, London, 1965, p. 34.

64. UdAL, JoHn SYmonds, Dorsetshire Folk-Lore, Hertford, 1922, p. 224; BLACK, op. cit., p. 157 (Somerset); Folk-Lore, 1909, 20, 218 (Oxfordshire); RADFORD, op. cit., p. 86 (Surrey).

65. Folk-Lore, 1943, 54, 304 (Devon); ibid., 1951, 62, 260 (Essex).

66. Folk-Lore, 1908, 19, 345. 


\section{Wayland D. Hand}

67. Sticker, Georg, Der Keuchhusten, Wien, 1896, p. 65 (citing an unidentified man by the name of Morris who prescribed this cure in the nineteenth century).

68. WuTtKe, Adolf, Der deutsche Volksaberglaube der Gegenwart, 3rd ed., MEYer, ElaRD HuGo, Berlin, Verlag Wiegandt \& Grieben, 1900, p. 361.

69. MCKeLVIE, op. cit., p. 279 , no. 138.

70. Publications of the Texas Folklore Society, 1930, 8, 82.

71. Folk-Lore, 1924, 35, 356.

72. Notes and Queries, 1st ser., vol. 5, 6 March 1852, p. 223.

73. Folk-Lore, 1945, 56, 270.

74. Leather, Ella M., The Folk-Lore of Herefordshire, Hereford, Jakeman \& Carver, 1912, p. 82; cf. Notes and Queries, 1st ser., vol. 5, 6 March 1852, p. 223 (where the mere sight of a piebald horse was held to effect the cure).

75. Notes and Queries, 6th ser., vol. 6, 18 November 1882, p. 407.

76. Campbell, MarIe, Folks Do Get Born, New York, Reinhart \& Company, 1946, p. 35 (Georgia: thrush); J. Am. Folklore, 1939, 52, 114, no. 62 (Tennessee: thrush); Thomas, Daniel Lindsey, and Thomas, LuCy Blayney, Kentucky Superstitions, Princeton, N. J., Princeton University Press, 1920, p. 118, no. 1380 (thrush); Hoosier Folklore, 1946, 5, 70, no. 25 (Illinois: tonsilitis).

77. Whitney, AnNIE Weston, and Bullock, Caroline Canfield, Folk-Lore from Maryland, Mem. Am. Folklore Soc., XVIII, New York, 1925, p. 87, no. 1774: J. Am. Folklore, 1927, 40, 166, no. 388 (Louisiana).

78. HyATT, op. cit., p. 212 , no. 4415 ; cf. also no. 4414.

79. HAND, op. cit., VI, 352, no. 2717.

80. Hudson, Arthur Palmer, Specimens of Mississippi Folk-Lore, Ann Arbor, Mich., 1928, p. 154, no. 2.

81. J. Am. Folklore, 1894, 7, 226.

82. Gregor, WALTER, Notes on the Folk-Lore of the North-East of Scotland, Publications of the Folk-Lore Society, VII, London, 1881, p. 132.

83. Hoosier Folklore, 1946, 5, 68, no. 3.

84. Tennessee Folklore Soc. Bull., 1953, 19, 2.

85. J. Am. Folklore, 1894, 7, 226; Folk-Lore, 1897, 8, 180 (both thrush: Ireland); New York Folklore Q., 1947, 3, 169 (whooping-cough).

86. Cf. HAND, op. cit., VI, 351, no. 2712 for the swallowing of live fish for whooping-cough.

87. BlaCK, op. cit., p. 36; HeNDERson, op. cit., pp. 140-41; (a trout); Balfour and Thomas, op. cit., p. 49 (a trout).

88. Notes and Queries, 5th ser., vol. 3, 1 June 1875, pp. 345-46.

89. J. Am. Folklore, 1891, 4, 125; FoGEL, op. cit., p. 339, no. 1805; Pennsylvania Dutchman, vol. 2, no. 11, 1 November 1950, p. 7.

90. Folk-Lore, 1943, 54, 303-4.

91. BLACK, op. cit., p. 35; Folk-Lore, 1911, 22, 455 (County Clare); ibid., 1929, 40, 117 (hold a small frog in the mouth of a child for awhile, and 'it will soon be heard whooping and wheezing all over the garden'); LEATHER, op. cit., p. 82 (thrush).

92. Handwörterbuch des deutschen Aberglaubens, 10 vols., Berlin and Leipzig, Walter de Gruyter, 1927-1942, vol. 3, p. 136; ANDEL, op. cit., p. 205.

93. New York Folklore Q., 1945, 1, 180.

94. Notes and Queries, 1st ser., vol. 3, 5 April 1851, 258.

95. Wright, JosePH (ed.), English Dialect Dictionary, 6 vols., reissue, Oxford, Oxford University Press, 1923, vol. 1, p. 586.

96. GuTCH, op. cit., p. 180.

97. J. Am. Folklore, 1892, 5, 62; WhITNEY and Bullock, op. cit., p. 83, no. 1710; Illinois Folklore, 1948, 2, 7.

98. PUCKeTt, op. cit., p. 371.

99. Indiana History Bull., 1958, 35, 134, no. 307. 


\section{Folk Medical Inhalants in Respiratory Disorders}

100. Folk-Lore, 1908, 19, 316.

101. Western Folklore, 1957, 16, 57 (news report from Dublin Irish Times, 21 July 1956.)

102. Midwest Folklore. 1961, 11, 47, nos. 150, 149, respectively; cf. no. 148.

103. Kentucky Folklore Record, 1955, 1, 70.

104. J. Am. Folklore, 1935,48 , p. 327 , no. 40 ; ibid., 1939, 52, p. 114, no. 67.

105. WHITNEY and BulLOCK, Op. cit., p. 83, no. 1710; RANDOLPH, op. cit., p. 136.

106. Brendle, Thomas R., and Unger, Claude W., 'Folk Medicine of the Pennsylvania Germans. The Non-Occult Cures', Proc. Pennsylvania German Soc., XLV, Norristown, Pa., 1935, p. 132 (for a child suffering from the 'blue cough'); Papers and Addresses of The Lebanon Co. Hist. Soc., 1905-1906, 3, 276; Fogel, op. cit., p. 337, no. 1791.

107. BRENDLE and UNGER, op. cit., p. 132; Fogel, op. cit., p. 337, no. 1792; AlLEN, op. cit., p. 84 (Illinois, and not noted as being of German origin). 